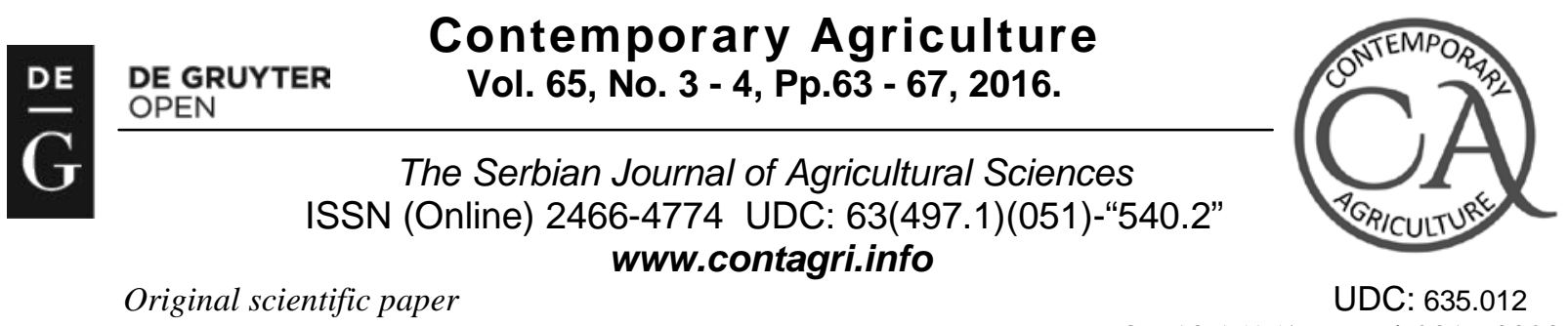

DOI: $10.1515 /$ contagri-2016-0020

\title{
EFFECT OF PLANT GROWTH REGULATORS ON THE PROPAGATION OF AFRICAN VIOLET(SAINTPAULIA IONANTHA H. WENDL.) FROM LEAF CUTTINGS
}

\author{
Emina MLADENOVIĆ ", Martina ZORIĆ, Jelena ČUKANOVIĆ, Ksenija HIEL, \\ Lazar PAVLOVIĆ, Ivana SENTIĆ ${ }^{1}$
}

Summary: The purpose of this paper is to examine the effects of commercial plant growth regulators (PGRs), namely Inict-1 and Incit-5, on the rooting of African violet leaf cuttings (Saintpaulia ionantha H. Wendl.). The production of African violets has grown considerably in recent years, thus it is important to study the most rapid and cost-effective means of mass production. The propagated plant material of the cultivar 'Nagano' was treated with Incit-1 and Incit-5. The following parameters were observed: the occurrence of the first root, the number of formed secondary roots and root lengths, the occurrence of the first leaf, and the occurrence of the first flower. The results obtained showed that the use of commercial rooting hormones, namely Incit-1 and Incit-5, exerted positive effects on the duration of rooting, the number of secondary roots formed, and the root lengths of African violets. During the research, it was observed that the rooting durations of all the plants treated with Incit-1 and Incit-5 were 5 days shorter. The results indicate that the plants treated with PGRs necessitate less time to root, less time to produce new leaves, and, consequently, less time to produce flowers.

Key words: African violet, phytohormones, Plant Growth Regulators, Naphthalene acetic acid (NAA),low-cost production

\section{INTRODUCTION}

The industry of ornamental plants has been growing in recent years (Jain 2006). Rout et al. (2006) argued that modern techniques of propagation have been developed in order to enable growers to meet the demands of the horticultural industry of the next century. They have also concluded that the most-produced genera of potted plants in the majority of developed countries are: Begonia sp., Ficus sp., Anthurium sp., Saintpaulia sp. and Spathiphyllum sp. The African violet (Saintpaulia ionantha H. Wendl.) belongs to the family Gesneriaceae and, owing to its characteristics, represents one of the most commercial pot species used in ornamental horticulture. Decorative colored flowers are the most important feature of African violets. Furthermore, the shape of flowers is very appealing as they can be flat and wavy. George et al. (1996) argued that the species belonging to the family Gesneriaceae are mainly micropropagated from buds or adventitious shoots which are directly regenerated on leaf sections. Although this is true, a majority of small producers are not able to work under laboratory conditions or purchase the equipment for micropropagation. The success of the African violet production has been increased by using phytohormones. Plant growth regulators (PGRs) are organic compounds other than nutrients that, in small amounts, promote, inhibit, or otherwise modify any physiological process in plants (Basra, 2000). One of the five established groups of PGRs is the group of auxins. According to Leakey (2003), the cuttings treated with auxins root more rapidly and produce more roots with a higher percentage of cuttings rooted. Therefore, this paper presents a low-cost solution for improving the leaf cutting propagation of African violets. Two commercial plant growth regulators(PGRs), namely Incit-1 and Incit-5, were used to treat the African violet leaf cuttings. The purpose is to determine which of the two investigated phytohormones yields better results, and which could be recommended for use in the mass production of African violets.

\footnotetext{
${ }^{1}$ Emina MLADENOVIĆ, PhD, Assistant Professor, Martina ZORIĆ, student, Jelena ČUKANOVIĆ, PhD, Assistant Professor, Ksenija HIEL, PhD, Assistant Professor, Lazar PAVLOVIĆ, MS, Teaching Assistant, Ivana SENTIĆ, MS, Teaching Assistant, University of Novi Sad, Faculty of Agriculture, Trg Dositeja Obradovića 8, 21000 Novi Sad

•Corresponding author: Emina MLADENOVIĆ, e-mail: eminam@polj.uns.ac.rs, tel: +381 0214853269
} 


\section{MATERIAL AND METHOD}

The initial cutting material was taken from ten different African violet plants (Saintpaluia ionantha H. Wendl.) Var. 'Nagano' (Figure 1). The copies of the mother plants are shown in Figure 4. For the purpose of this research, a total of 90 samples were taken.

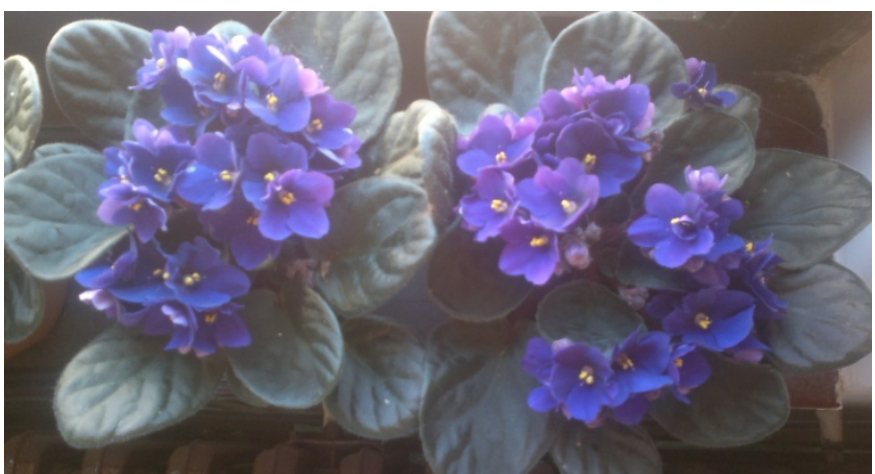

Figure 1.African violets, Saintpaulia ionantha H. Wendl. Var. 'Nagano'

A total of 90 samples of the African violet cultivar 'Nagano', obtained from commercial providers, were used in the research. The cultivar 'Nagano' belongs to a group of standard African violets. This plant is characterized by a simple, star-shaped, dark blue flowers. The abaxial surface of the leaf is hairy and dark green, whereas the adaxial surface of this variety is purple. Firm and healthy leaves were extracted from the plant material for propagation. The petioles with leaves attached were washed under running tap water and then sterilized by alcohol for 5 minutes. The sterilized plants were subsequently rinsed with distilled water three times. The substrate containing high-altitude (white) peat and lowland (black) peat in a 60:40 ratio respectively was thereafter used, with the addition of perlite and $\mathrm{pH} 6.5$.

Incit-1 and Incit-5 are rooting hormones which were used in the experiment. The lower parts of petioles, approximately $1 \mathrm{~cm}$ from the cut, were dipped in the hormones.Incit- 1 and Incit-5 contain plant hormones from the auxin family-1-NAA (1-naphthaleneacetic acid)in the concentrations of $0.1 \%$ and $0.5 \%$ respectively. There were three groups of plants in the experiment: the plants treated with Incit-1, the plants treated with Incit-5, and the control group. Each group consisted of 30 samples. Following the treatment with rooting hormones, the plants were planted in pots (Ø10) on 18 May 2015 (Figure 1). All pots were maintained in a greenhouse until the end of flowering at $25 \pm 1^{\circ} \mathrm{C}$. The following parameters were observed: the occurrence of the first root (days), the number of formed secondary roots and root lengths $(\mathrm{cm})$, the occurrence of the first leaf (days), and the occurrence of the first flower (days). The first measurement of root lengths was performed 19 days after planting, whereas the second was 6 days after the first measurement, and the third was 6 days after the second measurement.

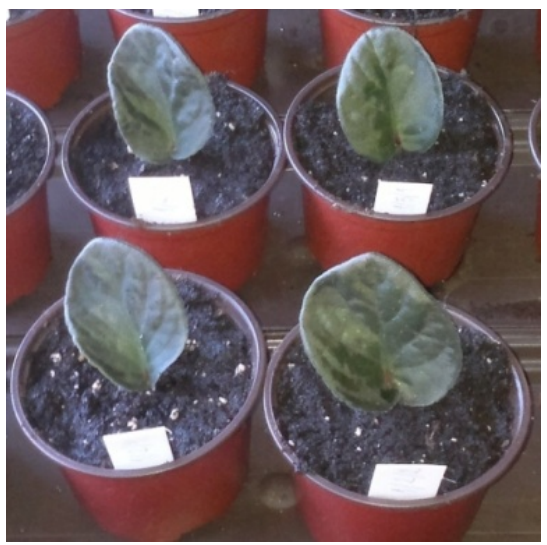

Figure2.Planted leaf cuttings of African violets (Saintpaulia ionanthaH.Wendl.) cv. 'Nagano’

\section{RESULTS}

The results showed that the rooting duration recorded for all 30 African violets within a group was shorter in the groups treated with Incit-1 and Incit-5 in comparison with the control group. The average rooting durations of the 
plants treated with Incit-1 and Incit-5, and the control plants were 25 days, 25 days and 30 days, respectively (Table 1). Consequently, a minimum period of time from the propagation to the first root occurrence was 19 days, whereas a maximum was 32 days. The results of root analysis showed that there were positive effects of rooting hormones Incit-1 and Incit-5 on the African violet root lengths and the number of formed secondary roots. The largest number of formed secondary roots (34) was observed in the group of African violets treated with Incit-5and the smallest (2) in the control group. The longest root $(2.2 \mathrm{~cm})$ was developed in the group of African violet leaf cuttings treated with Incit-5, whereas the shortest root length $(0.3 \mathrm{~cm})$ was measured in the control group (Table 1$)$.The results of other measured parameters also showed that the plants treated with the PGRs Incit- 1 and Incit- 5 required less time to produce the first leaf and flower in comparison with the non-treated plants. The average periods of time elapsed from the propagation to the first leaf occurrence for the non-treated plants and the plants treated with Incit-1 and Incit-5 were 78 days, 52 days, and 45 days, respectively. Moreover, the minimum (39 days) and maximum (84 days) values measured are shown in Table 1. The research results showed that the average periods of time elapsed from the propagation to the first flower occurrence (in days) vary in the instances of the non-treated African violets, and the African violets treated with Incit- 1 and Incit-5. On average, the African violets treated with Incit- 5 required the shortest time duration to produce the first flower (111 days since the propagation), whereas the first flower occurrence in the instance of the non-treated African violets lasted 135 days (on average). The data in Table 1 display the minimum and maximum values for this parameter with a difference of 37 days.

Table 1. Results of examined parameters: the occurrence of the first root (days), the number of formed secondary roots and root lengths (cm), the occurrence of the first leaf (days), and the occurrence of the first flower (days).

\begin{tabular}{|c|c|c|c|c|c|}
\hline \multicolumn{6}{|c|}{ Characteristics } \\
\hline $\begin{array}{l}\text { Examined African } \\
\text { violet groups }\end{array}$ & $\begin{array}{l}\text { Average number } \\
\text { of days until the } \\
\text { first root } \\
\text { occurrence }\end{array}$ & $\begin{array}{l}\text { Average number } \\
\text { of secondary roots }\end{array}$ & $\begin{array}{l}\text { Average root } \\
\text { length }(\mathrm{cm})\end{array}$ & $\begin{array}{l}\text { Average number } \\
\text { of days until the } \\
\text { first leaf } \\
\text { occurrence }\end{array}$ & $\begin{array}{c}\text { Average number } \\
\text { of days until the } \\
\text { first flower } \\
\text { occurrence }\end{array}$ \\
\hline Control group & 30 & 5.4 & 0.8 & 78 & 135 \\
\hline Incit- 1 treated & 25 & 12.2 & 1.1 & 52 & 120 \\
\hline Incit-5 treated & 25 & 17.2 & 1.5 & 45 & 111 \\
\hline $\mathrm{X}$ & 26.6 & 11.6 & 1.1 & 58.3 & 122 \\
\hline Min & 19 & 2 & 0.3 & 39 & 105 \\
\hline Max & 32 & 34 & 3.0 & 84 & 142 \\
\hline Std. & 2.9 & 5.9 & 0.4 & 17.4 & 12.1 \\
\hline CV (\%) & 10.8 & 51.0 & 32.5 & 29.8 & 9.9 \\
\hline
\end{tabular}

The results shown in Table 2 indicate the number of formed secondary roots and root lengths (cm) of the plants treated with Incit-1, Incit-5, and without the treatment in three measurements. The leaf cuttings which were treated with the rooting hormone Incit-5 had the largest average number of secondary roots (17.2 per plant) with a total of 517 secondary roots formed.

Table 2. Results of the number of formed secondary roots and root lengths ( $\mathrm{cm}$ ) in three measurements

\begin{tabular}{|c|c|c|c|c|c|c|c|c|c|c|c|c|}
\hline & \multicolumn{4}{|c|}{ The first measurement } & \multicolumn{4}{|c|}{ The second measurement } & \multicolumn{4}{|c|}{ The third measurement } \\
\hline & $\begin{array}{c}\text { Total } \\
\text { numb } \\
\text { er of } \\
\text { roots }\end{array}$ & $\begin{array}{l}\text { Averag } \\
\text { e } \\
\text { numbe } \\
\text { r of } \\
\text { roots }\end{array}$ & $\begin{array}{c}\text { Total } \\
\text { root } \\
\text { lengt } \\
\text { h } \\
(\mathrm{cm})\end{array}$ & $\begin{array}{c}\text { Averag } \\
\text { e root } \\
\text { length } \\
(\mathrm{cm})\end{array}$ & $\begin{array}{c}\text { Total } \\
\text { numb } \\
\text { er of } \\
\text { roots }\end{array}$ & $\begin{array}{l}\text { Averag } \\
\text { e } \\
\text { numbe } \\
\text { r of } \\
\text { roots }\end{array}$ & $\begin{array}{c}\text { Total } \\
\text { root } \\
\text { lengt } \\
\mathrm{h} \\
(\mathrm{cm})\end{array}$ & $\begin{array}{c}\text { Averag } \\
\text { e root } \\
\text { length } \\
(\mathrm{cm})\end{array}$ & $\begin{array}{c}\text { Total } \\
\text { numb } \\
\text { er of } \\
\text { roots }\end{array}$ & $\begin{array}{l}\text { Averag } \\
\text { e } \\
\text { numbe } \\
\text { r of } \\
\text { roots }\end{array}$ & $\begin{array}{c}\text { Total } \\
\text { root } \\
\text { lengt } \\
\mathrm{h} \\
(\mathrm{cm})\end{array}$ & $\begin{array}{c}\text { Averag } \\
\text { e root } \\
\text { length } \\
(\mathrm{cm})\end{array}$ \\
\hline $\begin{array}{l}\text { Control } \\
\text { group }\end{array}$ & 54 & 3 & 3.4 & 0.1 & 89 & 3.4 & 9 & 0.3 & 171 & 5.4 & 23.1 & 0.8 \\
\hline $\begin{array}{l}\text { Incit-1 } \\
\text { treated }\end{array}$ & 117 & 6.2 & 5.7 & 0.3 & 246 & 8.2 & 16.6 & 0.5 & 366 & 12.2 & 33.1 & 1.1 \\
\hline $\begin{array}{l}\text { Incit-5 } \\
\text { treated }\end{array}$ & 233 & 10.6 & 5.7 & 0.3 & 372 & 12.4 & 23.5 & 0.7 & 517 & 17.2 & 45.5 & 1.5 \\
\hline
\end{tabular}

The non-treated African violet leaf cuttings have $68.60 \%$ less formed secondary roots than the leaf cuttings treated with Incit-5, which on average amounted to 5.4 per plant and 171 formed secondary roots overall. Within the group of African violets treated with Incit-1,the overall number of formed secondary roots was 366, which on average amounted to 12.2 per plant. The number of formed secondary roots in the group of African violets treated with Incit1 was $29.07 \%$ less than in the group of African violets treated with Incit-5. The measured data of the average root 
length showed that the African violet leaf cuttings treated with Incit-5 had the longest formed roots. The overall length of formed roots in this group was $45.5 \mathrm{~cm}$, i.e. $1.5 \mathrm{~cm}$ per plant on average. All the roots formed in the control group were approximately one-half the length of the root cuttings treated with Incit-5. The overall length of formed roots in this group was $23.1 \mathrm{~cm}$, i.e. $0.8 \mathrm{~cm}$ per plant on average. The overall root length of the plants treated with Incit-1 was $33.1 \mathrm{~cm}$, i.e. $1.1 \mathrm{~cm}$ per plant on average. The results in this group were higher by $42.86 \%$ than in the control group and lower by $27.15 \%$ than in the group of leaf cuttings treated with Incit-5.

\section{DISCUSSION}

Tissue culture is the most common technique for producing healthy plant material with minimum time requirements and maximum funds invested. According to Pant (2014),high production costs area major impediment to the adoption of tissue culture raised products. However, some phytohormones used in vitro for the control of plant growth can also be used ex vitro for the improvement of plant growth. There are authors who claim that the application of root promoting growth regulatory substances (auxins) is the most common treatment to enhance rooting (Hartmann et al.,1997). The results in this research showed that the use of commercial rooting hormones, namely Incit-1 and Incit-5, exerted positive effects on the rooting duration, the number of secondary roots formed, and the length of roots of African violets (Figure 2).1-Naphthaleneacetic acid (1-NAA) is a plant hormone belonging to the family of auxins. It inhibits the growth of embryonic roots and stimulates the formation of secondary roots (Vinterhalter, et al., 1996). With NAA as an active substance of Incit-1 and Incit-5, these hormones were expected to indicate higher values of the examined parameters in the treated groups. African violets are plants which are easy to propagate by leaf cuttings (Stork et al., 2002). However, despite the recommendations by the manufacturer of Incit-1 and Incit-5, the use of Incit-5 resulted in higher values of all the examined parameters. According to Ghasemiet al. (2012), there is a positive correlation between the NAA concentration and the number of formed African violet roots. The results obtained during this research showed that Incit-5 (0.5\% NAA) exerted the most significant effects on the number of formed roots from the leaf cuttings of African violets, with the overall number of formed secondary roots amounting to 517.Furthermore, the greatest lengths of formed roots were recorded in the group of plants treated with Incit-5, with the overall root length of $45.5 \mathrm{~cm}$, i.e. $1.51 \mathrm{~cm}$ per plant on average. Although the length and the number of secondary roots greatly affect the growth of plants, these parameters are important for commercial nurseries and small producers as indicators of the rooting duration. According to Ghorbanzade et al. (2014),the propagation of African violets by traditional means of leaf cuttings is highly time-consuming.

With the growth of the horticultural industry, the African violet (Saintpaulia ionantha H. Wendl.) is an economically important ornamental plant with many varieties featuring diverse colors and shapes (Ghorbanzade et al., 2014).According to Poole et al. (2008), African violets have always been very popular with consumers and today are still near the top of the list with respect to the number of flowering plants sold yearly. According to Streck (2004), commercially, pot-grown flower plants, including African violets, are produced for specific marked dates. Therefore, there is a need to reduce the period of time from propagation to flowering, and ultimately introduce them to the market. Although there are numerous studies on improving the results of African violet propagation, most of them have been conducted in vitro with the high-cost equipment. Considering that the propagation of these plants by leaf cuttings is the most used method for commercial needs (Wolff, 2007), the results of this research providea widely available, low-cost solution for the enhancement of African violet rooting with the use of rooting hormones.

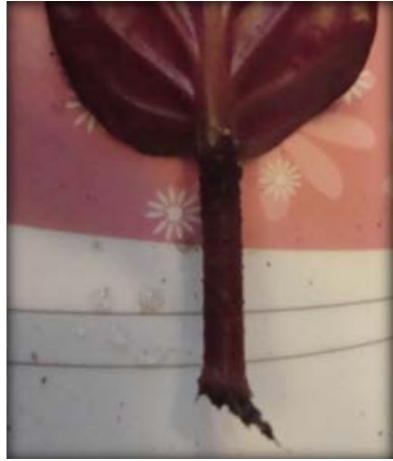

a) Control plant

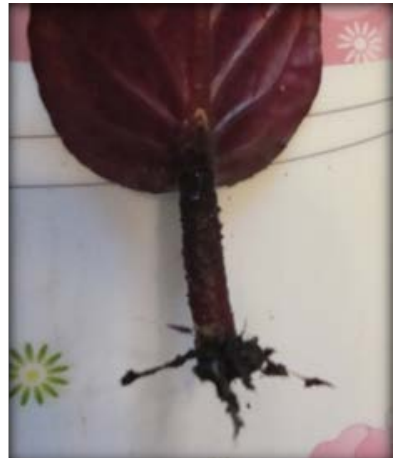

b) Plant treated with Incit-1

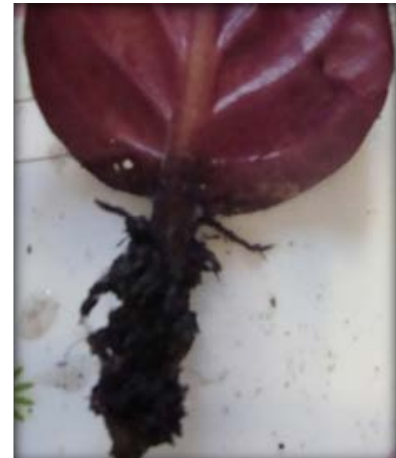

c)Plant treated with Incit-5

Figure 2.a-c. Root characteristics of all three examined groups of African violets 32 days after the propagation 


\section{CONCLUSION}

During this research, it was observed that the rooting durations of all the plants treated with Incit- 1 and Incit-5 were 5 days shorter. Although the emphasis was placed on the qualitative and quantitative root characteristics of African violets cv. 'Nagano', some other valuable characteristics of these plants were observed as well. The research results showed that the plants treated with PGRs necessitate less time to root, less time to produce new leaves, and, consequently, less time to produce flowers. These results confirm positive effects of the PGRs Incit- 1 and Incit-5 on the growth of African violets as a consequence of the rapid and high-quality root forming.

\section{REFERENCES}

ARTECA RN: Introduction to horticultural science. $2^{\text {nd }}$ ed.Cengage Learning, Stamford, pp. 117-120, 2015.

BASRA AS: Plant Grow Regulators in Agriculture and Horticuture. Their role and commercial uses. The Haworth press, pp. 1-16, 2000.

GHASEMI Y, NEMATZADEH GA, OMRAN VG, DEHESTANI A, HOSSEINI S: The effects of explant type and phytohormones on African violet (Saintpaulia ionantha H. Wendl.) micropropagation efficiency. Biharean Biologist, 6 (2) 73-76, 2012.

GEORGE EF: Plant Propagation by Tissue Culture. Part II. In Practice, $2^{\text {nd }}$ ed, Exegetics Ltd., Baringstoke, 1996.

GHORBANZADE Z, AHMADABADI M: An Improved System for Rapid in vitro Regeneration of Saintpaulia ionantha. Plant Tissue Cult.\& Biotech.24(1) 37-45, 2014.

HARTMANN HT, KESTER DE, DAVIS FT, GENEVE RL: Plant Propagation: Principles and Practices ( $6^{\text {th }}$ ed.), Prentice-Hall Inc, Upper Saddle River, New Jersey, USA,1997.

JAIN SM: Feeding the world with induced mutations and biotechnology. Proceedings of the International Nuclear Conference, Global trends and Perspectives. Seminar 1: Agriculture and Bioscience, Bangi, Malaysia, pp. 1-14, 2002.

LEAKEY RB: Physiology of vegetative reproduction. Encyclopedia of Forest Sciences, 2004.

PANT M: Minimal cost micropropagation protocol for Dianthus caryophyllus L.- a commercially significant venture. Indian Journal of Experimental Biology, 54, 203-211, 2016.

POOLE RT, OSBORNE RT, CHASE AR: African Violet Production guide, ARECA-A Foliage plant research Note RH-85-D,.2008.

ROUTH GR, MOHAPATRA A, MOHAN JAIN S: Tissue culture of ornamental pot plant: A critical review on present scenario and future prospects. Biotechnology Advances, 24, 531-560, 2006.

STRECK NA: A temperature response function for modeling leaf growth and development of the African violet (Saintpaulia ionanthaWendl.).Ciência Rural,34(1), 55-62, 2004.

VINTERHALTERD, VINTERHALTER B: Kultura in vitro imikorporpagacijabiljka. Axial,Beograd,1996.

WOLFF J: Enciklopedija sobnog cveća,Akia M. Princ, Beograd,2007

\section{UTICAJ REGULATORA RASTA NA RAZMNOŽAVANJE AFRIČKE LJUBIČICE (SAINTPAULIA IONANTHA H. WENDL.) LISNIM REZNICAMA}

Izvod : U radu je prikazan uticaj komercijalnih preparata za ožiljavanje(PGRs), Incit-1 i Incit-5 na razvoj korena afričke ljubičice (Saintpaulia ionantha $\mathrm{H}$. Wendl.). Zbog porasta proizvodnje ovih biljaka, tokom poslednjih godina, neohodno je ispitati nove načine prozvodnje koji će biti ekonomski isplativi i omogućiti brzu masovnu proizvodnju. U radu je korišćen umnoženi sadni materijal sorte "Nagano" koji je tretiran sa Incit-1 i Incit-5. Parametri koji su praćeni su: pojava prvog korena, broj formiranih sekundarnih korena i dužinu korena, pojava prvog lista i pojava prvog cveta. Rezultati istraživanja pokazali su da je upotreba komercijalnih hormona za ožiljavanje, Incit-1 i Incit-5 ima pozitivan efekat na: vreme pojave prvog korena, broj formiranih sekundarnih korena i dužinu korena afričke ljubičice. Tokom istraživanja uočeno je da su sve biljake,tretirane sa Incit-1 i Incit-5,formirale koren 5 pre kontrolnih biljaka. Pored toga rezultati ovog istraživanja su pokazali da biljke tretirane sa PGRs ne samo da im je potrebno manje vremena za formiranje korena, nego je potrebno manje vremena za formiranje novih listova i cvetova.

Ključne reči: afrička ljubičica, biljni hormoni, preparati za ožiljavanje, NAA, ekonomski isplativa proizvodnja.

Received / Primljen: 07.10.2016

Accepted / Prihvaćen: 18.11.2016. 